\title{
Hypoglycemic potential of Anacardium occidentale L.
}

\begin{abstract}
Diabetes results from defects in insulin secretion and its action. It is often associated with insulin resistance, obesity, dyslipidemia and hypertension, being regarded as a metabolic syndrome. Diabetes therapy is based, in general, decrease in insulin resistance, improvement of the function of pancreatic beta cells with physical activities and diet, oral hypoglycemic agents, anti-obesity and anti-hyperglycemic agents. New drugs with hypoglycemic effect have been investigated. This mini review presents the pharmacological perspectives of $A$. occidentale in the treatment of diabetes.
\end{abstract}

Keywords: diabetes, hypoglycemic plant, anacardic acid, cardanol, cardol
Volume 7 Issue 2 - 2018

\author{
Ivanete Cardoso Palheta, Lanalice Rodrigues \\ Ferreira \\ Instituto de Ciências da Saúde, Universidade Federal do Pará, \\ Brasil \\ Correspondence: Ivanete Cardoso Palheta,Instituto de \\ Ciências da Saúde, Universidade Federal do Pará, 66075-II0, \\ Belém, PA, Brasil, Email ivapalheta@gmail.com
}

Received: February 20, 2018 | Published: March 21, 2018

\section{Introduction}

Diabetes describes a multiple etiology metabolic disorder characterized by hyperglycemia resulting from defects in insulin secretion and action. ${ }^{1}$ It is estimated that this metabolic disorder affects about 382 million people worldwide, reaching 471 million in $2035 .{ }^{2}$ Hyperglycemia associated with diabetes represents a risk factor in cases of retinopathy, neuropathy and nephropathy, in addition, it is strongly related to the progression of several cardiovascular diseases. ${ }^{3}$ The search for hypoglycemic drugs has increased to find more effective treatments or to discover new strategies to control the disease. Diabetes therapy is generally based on decreased insulin resistance, improved pancreatic beta cell function, oral hypoglycemic agents, antihyperglycemic agents and anti-obesity agents. ${ }^{4}$

Human disorders have been treated for years with organic substances derived from or derived from plants, which represent the major sources of bioactive substances for therapeutic use, mainly due to the structural diversity of biosynthesized secondary metabolites. ${ }^{5}$ Anacardium occidentale L. (Anacardiaceae) is a native plant not endemic to Brazil, which appears among species frequently used ethnopharmacologically ${ }^{6,7}$ and investigated experimentally ${ }^{8}$ in the treatment of diabetes. It is considered natural source of phenolic compounds, carotenoids, flavonoids, tannins, which confer plant antioxidant activity, antidiabetic agents, gastroprotective, anticancer and antimicrobial actions. ${ }^{9}$ This mini review presents the pharmacological perspectives of $A$. occidentale in the treatment of diabetes.

\section{Hypoglycemic potential of compounds isolated from $A$. occidentale}

Among the major compounds isolated from A. occidentale are anacardic acid, cardanol and cardol which have hydrophobic side chains with different degrees of unsaturation, including the saturated compound, monoene, diene and triene. ${ }^{10}$ Anacardic acid is considered an important $\alpha$-glucosidase inhibitor, ${ }^{11}$ delaying glucose absorption, presenting potential for the treatment of postprandial hyperglycemia. While the anacardic acid inhibits the aldose reductase ${ }^{10}$ which acts on various hexoses and is present in tissues that commonly suffer from diabetes complications such as capillaries and vascular endothelium (retina, crystalline) and peripheral nerves (Schwan cells). Tolrestat, an important aldose reductase inhibitor, has been shown to be efficacious in the treatment and prevention of neuropathy, nephropathy and diabetic retinopathy, reducing the gravity of chronic tissue damage associated with hyperglycemia. ${ }^{12}$ The antioxidant activity of anacardic acid $\left(\mathrm{IC}_{50}=0.6 \mathrm{Mm}\right)$, cardanol and cardol $\left(\mathrm{IC}_{50}<0.4 \mathrm{Mm}\right)$ was elucidated..$^{13}$ The action of anacardic acid against reactive species was mainly associated with its ability to inhibit oxidative enzymatic forms. ${ }^{10}$ Hyperglycemia is characterized by a state of high oxidative stress, related to the genesis of chronic complications in diabetes, ${ }^{14}$ so it has been proposed that the use of antioxidants would inhibit the progression and development of complications associated with diabetes (Figure 1)..$^{15}$<smiles>[R]c1cccc(O)c1C(=O)O</smiles><smiles>Oc1cccc(I)c1</smiles>
cardanol<smiles>[R]c1cc(O)cc(O)c1[R]</smiles>
anacardic acid

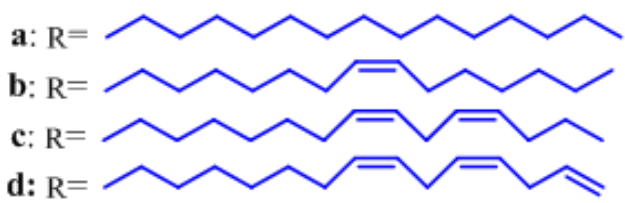

Figure I The major components of A. occidentale.

\section{In vivo preclinical studies with extracts of $A$. occidentale}

In addition to compounds already isolated, studies have shown the hypoglycemic potential of extracts obtained from $A$. occidentale. Investigations using the hexane extract of leaves elucidated the hypoglycemic effect in insulin-dependent rats with streptozotocin induced diabetes mellitus. At the dose of $300 \mathrm{mg} / \mathrm{kg} / \mathrm{day}$ there was a significant reduction in the level of blood glucose, total excreted protein, glycosuria and urea. ${ }^{16}$ Fractions of hexane and ethyl acetate have been shown to be more potent in the treatment of diabetic rats when compared to extracts obtained with methanol and dichloromethane. ${ }^{17}$. At a dose of $100 \mathrm{mg} / \mathrm{kg}$ ethanolic fractions of leaf 
extracts of $A$. occidentale reduced the blood glucose levels of diabetic rats compared to the effect of treatment with pioglitazone, used as standard drug. ${ }^{18}$ A reduction of the plasma glucose level in alloxan induced rats at doses of 34,200 and $300 \mathrm{mg} / \mathrm{kg}^{19}$ was observed, analyzing the hypoglycemic effect of the ethanolic extract from A. occidentale reddish bark. These results can be supported by the presence of polyphenols and flavonoids in the plant extract.

\section{Conclusion}

This mini review reinforces the pharmacological potential of A. occidentale for the treatment of diabetes. The isolated major compounds of this species can be analyzed as prototypes for the development of novel molecules for the treatment of human diseases such as diabetes, the various pathophysiology still without effective treatment, thus highlighting the need for research in this area.

\section{Acknowledgements}

None.

\section{Conflict of interest}

The Author declares there is no conflict of interest.

\section{References}

1. Ferreira LT, Saviolli IH, Valenti VE, et al. Diabetes melito: hiperglicemia crônica e suas complicações. ABCS Health Sciences. 2011;36(3):182188.

2. Diretrizes SBD. Epidemiologia e prevenção do diabetes mellitus. Rio de Janeiro. AC Farmacêutica. pp.390.

3. Conceição RA, Silva PN, Barbosa MLC. Fármacos para o Tratamento do Diabetes Tipo II: Uma Visita ao Passado e um Olhar para o Futuro. Rev Virtual Quim. 2017;9(2):514-534.

4. Weinert LS, Camargo EG, Silveiro SP. Tratamento medicamentoso da hiperglicemia no diabetes melito tipo 2. Rev HCPA. 2010;30(4):372-381.

5. Viegas C, Bolzani VS. Os produtos naturais e a química medicinal moderna. Quimica Nova. 2006;29(2):326-337.

6. Alvarenga CF, Lima KMN, Mollica LR, et al. Uso de plantas medicinais para o tratamento do diabetes mellitus no Vale do Paraíba-SP. Rev Ciên Saúde. 2017;2(2):36-44.

7. Palheta IC, Tavares-Martins ACC, Lucas FCA, et al. Ethnobotanical study of medicinal plants in urban home gardens in the city of Abaetetuba, Pará state, Brazil. Boletín Latinoamericano y del Caribe de Plantas Medicinales y Aromáticas. 2017;16 (3):206-262.
8. Saidu, AN, Mann A, Balogun S. The Hypoglycemic Effect of Aqueous Extract of the Anacardium occidentale Linn Leaves Grown in Nigeria on Normoglycemic Albino Rats. JETEAS. 2012;3(2):302-308.

9. Brijyog, Singh LP, Maiti A. Pharmacological importance of Anacardium occidentale: a review. AJPER. 2017;6(1):40-51.

10. Hamad FB, Mubofu EB. Potential Biological Applications of Bio-Based Anacardic Acids and Their Derivatives. Int J Mol Sci. 2015;16(4): 85698590.

11. Toyomizu M, Sugiyama S, Jin RL, et al. A-Glucosidase and aldose reductase inhibitors: constituents of cashew, Anacardium occidentale nut shell liquids. Phytotherapy Research. 1993;7(3):252-254.

12. Fruncillo MDR, Troy MSS, Parker V, et al. Pharmacokinetics of the aldose reductase inhibitor tolrestat: Studies in healthy young and elderly male and female subjects and in subjects with diabetes. Clin Pharmacol Ther. 1996;59(6):603-612.

13. Trevisan MTS, Pfundstein B, Haubner R, et al. Characterization of alky phenols in cashew (Anacardium occidentale) products and assay of their antioxidant capacity. Food Chem Toxicol. 2006;44(2):188-197.

14. Brownlee M. The pathobiology of diabetic complications: a unifying mechanism. Diabetes. 2005;54(6):1615-1625.

15. Schmidt AM, Stern D. A radical approach to the pathogenesis of diabetic complications. Tendências Pharmacol Sci. 2000;21(10):367-369.

16. Tedong L, Dimo T, Dzeufiet P, et al. Antihyperglycemic and renal protection activities of Anacardium occidentale (Anacardiaceae) leaves in diabetic rats induced streptozotocin. The African Journal of Traditional. 2006;3(1):23-35.

17. Sokeng SD, Lontsi D, Moundipa PF, et al. Hypoglycemic effect of Anacardium occidentale L. methanol extract and fractions on streptozotocin-induced diabetic rats. Global Journal of Pharmacology. 2007;1(1):01-05

18. Jaiswal YS, Tatke PA, Gabhe SY, et al. Antidiabetic activity of extracts of Anacardium occidentale Linn. leaves on $\mathrm{n}$-streptozotocin diabetic rats. $J$ Tradit Complement Med. 2017;7(4):421-427.

19. Abdullahi S, Olatunji GA. Antidiabetic activity of Anacardium occidentale in alloxan - diabetic rats. Journal of Science and Technology. 2010;30(3):35-41. 